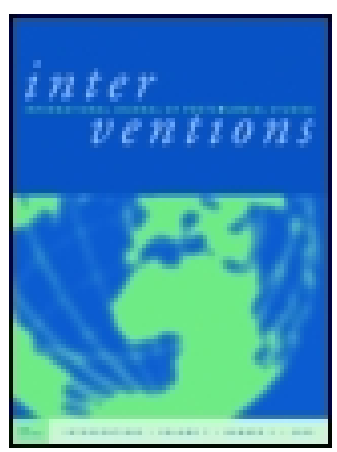

Interventions

International Journal of Postcolonial Studies

ISSN: 1369-801X (Print) 1469-929X (Online) Journal homepage: https://www.tandfonline.com/loi/riij20

\title{
Kafka, the Caribbean, and the Holocaust
}

\section{Jason Frydman}

To cite this article: Jason Frydman (2019): Kafka, the Caribbean, and the Holocaust, Interventions, DOI: 10.1080/1369801X.2019.1585914

To link to this article: https://doi.org/10.1080/1369801X.2019.1585914

册 Published online: 28 Mar 2019.

Submit your article to this journal

Џ Article views: 2

View Crossmark data $\asymp$ 


\section{KAFKA, THE CARIBBEAN, AND THE HOLOCAUST}

\section{Jason Frydman}

English Department and Caribbean Studies [Program], Brooklyn College, City University of New York, USA

This essay reexamines the figure of Franz Kafka (1883-1924) in light of his largely ignored, recursive links to circum-Caribbean and Black Atlantic

Africa

Auschwitz

Black Atlantic

Caribbean

Eurocentrism

genocide

German

colonialism

Holocaust

imperialism

Kafka, Franz processes of racialized exploitation and corporal punishment. When we centre Kafka's extensive biographical and literary engagements with these processes, the persistent debate over Kafka's status as a Holocaust prophet emerges in a new light. Kafka's archival trail connects his lifelong attention to African enslavement and New World plantation economies to his nightmarish vision of murderous bureaucracies - a connection that crystallizes concretely in his 1919 short story "In the Penal Colony." The archival and aesthetic connections direct us to a historiographical one, namely the increasingly excavated genealogical linkages between the Holocaust and anterior genocidal depredations in Africa and the New World under the auspices of European colonialism. This historiographical reorientation allows us to recast, in a global frame, the debate over Kafka's status as a prophet of world history, a debate that has heretofore operated through the exclusion of the transatlantic slave trade. Kafka's extensively documented attunement to colonial political economies provides formal, figural mechanisms that not only link the juridical-economic worlds of 
prophet

slavery

transatlantic slave trade
Caribbean slavery and Hitler's Third Reich, but also anticipate, and disable, the dehistoricized, Eurocentric appropriation of his textual archive as a premonition of Auschwitz.

Nearly twenty years ago, by uncovering the source of Hegel's master-slave dialectic in the Haitian Revolution, Susan Buck-Morss's "Hegel and Haiti" (2000) reminded readers of what Edward Said (1993, 80-97) had highlighted years earlier in his analysis of Jane Austen's reliance on the sugar plantations of Antigua in Mansfield Park: the European cultural tradition's all-encompassing integration with, dependency on, and responsiveness to New World slavery. Recent intellectual energy associated with the Black Lives Matter campaign has reanimated this call for rereading our monumental figures textual as well as sculptural - "in the wake" of an anti-Blackness that persistently excludes through "accumulated erasures, projections, fabulations, and misnamings" the lacerating presence of race (Sharpe 2016, 12). This essay reexamines the figure of Franz Kafka (1883-1924) in light of his largely ignored, recursive links to circum-Caribbean and Black Atlantic processes of racialized exploitation and corporal punishment. When we centre Kafka's extensive biographical and literary engagements with the plundering and destruction of Black bodies, the persistent debate over Kafka's status as a Holocaust prophet emerges in a new light. Kafka's archival trail connects his lifelong attention to African enslavement and New World plantation economies to his nightmarish vision of murderous bureaucracies - a connection that crystallizes concretely in his 1919 short story "In the Penal Colony." The archival and aesthetic connections direct us to a historiographical one, namely the increasingly excavated genealogical linkages between the Holocaust and anterior genocidal depredations in Africa and the New World under the auspices of European colonialism. This historiographical reorientation allows us to recast, in a global frame, the debate over Kafka's status as a prophet of world history, a debate that has heretofore operated through the exclusion of the transatlantic slave trade. Kafka's extensively documented attunement to colonial political economies provides formal, figural mechanisms that not only link the juridical-economic worlds of Caribbean slavery and Hitler's Third Reich, but also anticipate, and disable, the dehistoricized, Eurocentric appropriation of his textual archive as a premonition of Auschwitz.

Kafka, famously, refused to publish much of his work; yet the slender offerings he did disseminate quickly made people feel there was something prophetic about them. Gustav Janouch, a young friend of Kafka's in a Prague whose long familiarity with the faceless bureaucracy of the Austro-Hungarian Empire was suddenly sutured to the mechanized devastation of the Great War, asked him whether his work was not a "mirror of tomorrow" 
(Janouch 1971, 150). Not long after, in a series of letters in 1938, five years into the rise of the Third Reich, Walter Benjamin and Gershom Scholem also took up the question of Kafka as prophet. In a prescient figuration of his own, Benjamin wrote:

Kafka's world ... is the exact complement of his era which is preparing to do away with the inhabitants of this planet on a considerable scale. The experience which corresponds to that of Kafka, the private individual, will probably not become accessible to the masses until such time as they are being done away with. (Benjamin 1969, 143)

Yet, ultimately, two years before his suicide as he feared being turned over to the Gestapo on the Franco-Spanish border, Benjamin claimed, “There was no far-sightedness, or 'prophetic vision'. Kafka listened to tradition and he who listens hard does not see" (143). Writing in 1944, as the scale of the Final Solution had just begun to come into view, Hannah Arendt nonetheless followed Benjamin's lead and disavowed the mantle of prophecy: "Kafka's so-called prophecies were but a sober analysis of underlying structures which today have come into the open" (Arendt 1994, 74). By the late 1960s, as the overwhelming scope of the Nazis' continental death machine began to emerge in Europe and North America through the efforts of historians such as Raul Hilberg, intellectuals such as George Steiner and Theodor Adorno reasserted Kafka's status as Holocaust prophet, a position that became more or less axiomatic. In a landmark 1986 essay, "Kafka as Holocaust Prophet - A Dissenting View," Lawrence Langer reduced these figures symptomatically to "an urgent but misdirected modern need to find in past art (if not past history) 'logical' precedents for the unprecedented illogic of the Holocaust" $(1995,113)$. For Langer, this "modern need" to identify the oracular in Kafka pushes Steiner to embrace "dubious evidence," "careless reading," and "excessive claims," while Adorno "intrudes his own political-economic convictions" and as a result "the pseudo-equivalence between Kafka and Nazism verges on the absurd" $(110,115)$. And yet, as Russell Samolsky notes in a recent foray into the Kafka-as-prophet debate, "despite the seeming cogency of Langer's critique and the large and implausible assertions of Steiner," a persistent sense still exists among Kafka's readers that he is prescient, oracular, prophetic $(1999,176)$. Samolsky argues in turn that "prophecy" is a textual effect of Kafka's "preparatory anxiety" colliding with the Shoah, "a trauma in the Freudian sense, in that it generates its own retroactive antecedents" (191). For Langer, Samolsky's analysis might help to clarify the formal devices which poised Kafka's oeuvre to satisfy "an urgent but misdirected modern need;" nonetheless, in Langer's argument, reading Kafka as a prophet results from retrospectively imposing historical facts on Kafka's texts, which is not only anachronistic, but also "any 
direct political allusion would have violated the hermetic spirit of Kafka's approach" (Langer 1995, 115).

This sense of Kafka's "hermetic spirit” has loomed large in Kafka's reception. Many readers, scholars, biographers, translators, and critics of Kafka have framed him primarily as an allegorist, abstracting the nightmare of techno-bureaucratic modernity from any historical or geographical specificity. The evasiveness of Kafka's fiction, that "hermetic spirit," of course makes it perilous to attempt to find one-to-one correspondences between his texts and historical events. Yet a strong tradition of interpreting "In the Penal Colony" has grounded itself in specific historical data, from Walter Müller-Seidel's (1986) attention to fin-de-siècle debates over deportation and racial degeneracy to Sander Gilman's (1995, 66-88) subsequent interpretation of the story as an exploration of Jewish racialization, illness, and gender through the fictionalization of Albert Dreyfus's imprisonment on Devil's Island. The racial-geographical hermeneutics of the story expand as Robert Lemon responds to Elizabeth Boa's suggestion that the story's reference to the Prisoner's " 'wulstig' ('thick') lips can be construed as a 'racist marker suggesting African features'," countering that "this hint hardly accords with the ostensible setting of the tropical Far East, as suggested by the teahouse" (Boa 1996, 139; Lemon 2007, 282). Lemon, pushing beyond the focus on Far East Orientalism established most prominently by Rolf Goebel (1997), returns us to an evasive, hermetic Kafka when he reminds us that "the text places the figure of the convict in all the subject positions available in the context of the penal colony: the colonized native, the degenerate deportee, and the lowly soldier" (Lemon 2007, 282).

Through such gestures of self-reflexivity and overdetermination, what Richard Gray has called "disjunctive signs" that overload and interrupt the mediation across subject positions, Kafka's poetics regularly confound the efforts of interpreters to ground their readings in sharply delimited historical-material contexts $(2002,214)$. In fact, Axel Hecker argues the two primary interlocutors of "In the Penal Colony," the Traveler and the Officer, anticipate the dialectics of the story's reception, an undecidable engagement between allegorical and literal-historical interpreters (1998, 115-117). In the face of such overdetermination and undecidability, this essay will nonetheless read "In the Penal Colony" attending to the depth of Kafka's interest in the Black Atlantic colonial world, an interest directly fed by people like his Uncle Josef, who served as Chief of Commercial Enterprises for the Congo Railway in the Belgian Congo before joining business ventures connected to the construction of the Panama Canal, built primarily with West Indian labour (Northey 1991, 15-30). As a less directly mediated engagement with Black Atlantic colonial political economy, Kafka's vast if idiosyncratic reading habits returned again and again to the settler colonies of German Southwest and East Africa, as well as the plantations and penal colonies of 
the circum-Caribbean. In light of these interests and investments, I propose to reread "In the Penal Colony" with an eye toward substantiating them as relevant to the background and context of the story and also to his emergent vision of the juridical-economic construction of a pained and criminalized [Black] subjectivity that bears directly on his "premonition" of, his "preparatory anxiety" over, Jewish suffering in the Holocaust.

Written in 1914 and published in 1919, though read publicly on multiple occasions in between, "In the Penal Colony" takes place on an unnamed tropical island of the French Empire. There, a Traveler encounters an Officer, second in command to the New Commandant, yet still a partisan of the late Old Commandant. The Traveler has been invited to evaluate the penal colony's administration of justice, in particular the use of what Kafka calls "the apparatus [der Apparat]." Klaus Wagenbach's critical edition features many historical and technical diagrams that may have inspired this contraption, including some Kafka encountered evaluating patents and worksites for the Worker's Accident Insurance Institute for the Kingdom of Bohemia (Der Arbeiter-Unfall-Versicherungs-Anstalt für das Königsreich Böhmen), where he worked for most of his adult life (Kafka 1975, 66-68). The most useful close relation may be the printing press, not only for its overall shape and subordinate mechanisms, but also for its functionality. For the apparatus, while an instrument of punishment, punishes through inscribing the Law on its victims. The Officer explains:

Do you understand the process? The harrow is starting to write. When it's finished with the first part of the script on the man's back, the layer of cotton wool rolls and turns the body slowly onto its side to give the harrow a new area. Meanwhile those parts lacerated by the inscription are lying on the cotton wool which, because it has been specially treated, immediately stops the bleeding and prepares the script for a further deepening. Here, as the body continues to rotate, prongs on the edge of the harrow then pull the cotton wool from the wounds, throw it into the pit, and the harrow goes to work again. In this way it keeps making the inscription deeper for twelve hours.” (Kafka, n.d., 7; hereafter cited solely by page number)

A lethal combination of printing press, tattoo gun, and cotton gin, the Apparatus once stood at the centre of the penal colony's legal process. Now, however, under the rule of the New Commandant, it is falling out of favour. "Judgments" no longer draw the same large crowds of spectators. Replacement parts arrive slowly from the metropole. The Officer, while discouraged, has not lost any enthusiasm for the old ways, however. With the assistance of the Soldier, he prepares the Condemned Man for punishment. Meanwhile, the Traveler asks: 
"Does he know his sentence?" "No," said the Officer. He wished to get on with his explanation right away, but the Traveler interrupted him: "He doesn't know his own sentence?" "No," said the Officer once more. He then paused for a moment, as if he was asking the Traveler for a more detailed reason for his question, and said, "It would be useless to give him that information. He experiences it on his own body." (7)

The Condemned Man neither knows his own sentence "nor has had any opportunity to defend himself" (4). As the Officer proclaims: "The basic principle I use for my decisions is this: Guilt is always beyond a doubt" (5). The Condemned learns of his crime by means of his punishment:

For the first six hours the condemned man goes on living almost as before. He suffers nothing but pain ... But how quiet the man becomes around the sixth hour! The most stupid of them begin to understand. It starts around the eyes and spreads out from there. A look that could tempt one to lie down under the harrow. Nothing else happens. The man simply begins to decipher the inscription. He purses his lips, as if he is listening. You've seen that it's not easy to figure out the inscription with your eyes, but our man deciphers it with his wounds. (8)

The Condemned Man, a Captain's servant, should have been executed for falling asleep on duty; after being whipped, he "grabbed his master by the legs, shook him, and cried out, 'Throw away that whip or I'll eat you up!'” (5). However, when the Apparatus begins to malfunction in the process of inscribing "Honor thy superiors," the Officer succumbs to that "tempt [ation] to lie down under the harrow." With manic devotion to the machine, he straps himself in for a fatal self-mangling that sends the Traveler running to the port and on to a boat that carries him away as the Soldier and Condemned Man desperately attempt, and fail, to get on board.

"In the Penal Colony" stages the predicament of the individual before law and authority in ways that resemble major Kafka works such as The Trial and The Castle. The Condemned Man stands not only accused, but therefore also shamefully tainted, regardless of any subsequent judgment. Only the perversity of the officials themselves may divert the course of proceedings. The shenanigans of marginal characters ludicrously embellish the spectacle of discipline and punishment. Meanwhile, the straight man attempts to maintain a posture of well-measured reason in the face of the absurd and bloody fiasco transpiring around him. Just as Steiner will read in The Trial "the classic model of the terror state" $(1970,121)$ and Adorno will note that in The Castle "the officials wear a special uniform, as the SS did" (1981, 259), Günther Anders sees in the apparatus "a highly complex and diabolically conceived execution-machine, such as the world had never seen before the time of Hitler's instruments of mass murder" (1960, 14-15). Thus, Kafka's fictional 
creations solicit their proleptic status, "premonitions of Auschwitz," as Hillis Miller writes in his study of literature before and after the Holocaust (2011, 38).

This look forward toward the Final Solution, rather than backward toward those colonial places and histories in Africa and the New World that Kafka studied, and that "In the Penal Colony" geographically evokes, confines both the debate over Kafka's status as a Holocaust prophet, and the implicit corollary debate over the Holocaust as an event without precedent, to narrow European confines. Like nearly all participants on either side of the Kafka-asprophet debate, Hillis Miller - who admirably stands out for attending to the figural resonances between Kafka, Holocaust literature, and the literature of slavery - nonetheless evinces this geographical cordon sanitaire when he claims:

Auschwitz was a decisive turning point in history. It was the moment when the German-speaking region of Europe, the region that produced some of Western culture's highest achievements - Beethoven, Kant, Hegel, the Jena school, not to speak of Marx, Rilke, Thomas Mann, Wittgenstein, Heidegger, and Kafka - could murder six million Jews in a technologically and bureaucratically enhanced monstrous genocide. (Miller 2011, x)

To claim that Auschwitz is a decisive turning point, one that Kafka uniquely presaged, raises a problem with respect both to world history and Kafka's engagement with that history. To begin with, it was not the first "technologically and bureaucratically enhanced monstrous genocide" in German history. In the decades following the 1884-5 Berlin Conference that divided Africa into spheres of European operation, Imperial Germany attempted to open Southwest Africa and East Africa to resource extraction and settler colonialism, a process documented in books Kafka owned, including Max Wiederhold's Im Hinterlande von Deutsch-Ostafrika (In the Hinterlands of German East Africa, 1910) and Erich von Salzmann's Im Kampfe gegen die Hereros: Bilder aus dem Feldzug in Südwest (The Fight against the Herero: Portraits from the South West Military Campaign, 1911) (Born 1990, 235255). In light of resistance from the indigenous Herero between 1904 and 1907 the German General Staff planned and executed what they approvingly referred to in their official newspaper Der Kampf (The Fight) as "the extermination of the Herero nation" (Bley 1971, 162). In a letter General Lothar von Trotha wrote before one of the operations in this campaign, which was covered extensively in the Prager Tagblatt, which Kafka read almost daily for much of his adulthood: "The nation as such should be annihilated" (Mamdani 2001, 11). However, this was not merely a campaign of ethnic cleansing and genocide: it was an economic operation. Herero were pressed into slave labour to build the railroads that would not only carry them to 
the concentration camps they would also build, but that would additionally open up Lebensraum in the habitable interior of the region to German settlement. Concentration camp prisoners such as those at Shark Island, after a selection process determining who was fit and unfit for work (the unfit were often subjected to medical experimentation), continued to provide slave labour to the German military and settlers, until they fulfilled the prophecy of their pre-printed death certificates, which read: "death by exhaustion following privation” (Hartmann, Silvester, and Hayes 1999, 118).

The vocabulary of "extermination," "concentration camps," "Lebensraum," "medical experimentation," and "selection processes," as African historians such as Mahmood Mamdani (2001) and Shelley Baranowski (2011) have observed, has become indissolubly linked with the Nazi's "final solution to the Jewish question" ratified at the Wannsee Conference on 20 January 1942. Holocaust historiography, by turn, has emphasized how the final solution to the Jewish question entailed not only the deportation and murder of Europe's Jewish population, but also their minutely calculated distribution as slave labour to the chemical, munitions, and textile factories of the Nazi war machine (Megargee 2009, n.p.). In a chilling echo of the German General Staff's management of the indigenous African question, the Protocol of the Proceedings of the Wannsee Conference of January 1942 mandated:

In the course of the final solution and under appropriate direction, the Jews are to be utilized for work in the East in a suitable manner ... In the process a large number of them will undoubtedly be eliminated by natural causes. (Heydrich 2016)

Echoing the editors of the recent volume German Colonialism: Race, the Holocaust, and Postwar Germany, Auschwitz seems less like a turning point in this light, a future Kafka prophesied, than a repetition, "the colonial aspects of the Nazi project" (Langbehn and Salama 2011, ix) reminding us of Aimé Césaire's $(1955,7)$ gloss on genocidal fascism in Europe: the "choc en retour" (blowback) of colonialism abroad.

Hannah Arendt to some degree recognized this, which may help account for her skepticism toward the acclamation of Kafka as a prophet. She devoted one volume of The Origins of Totalitarianism to imperialism, and in the chapter entitled "Race and Bureaucracy" she draws a line from the scramble for Africa to the Third Reich:

Race was the emergency explanation of human beings whom no European or civilized man could understand and whose humanity so frightened and humiliated the immigrants that they no longer cared to belong to the same human species ... This answer resulted in the most terrible massacres in recent history, the Boers' extermination of the Hottentot tribes, the decimation of the peaceful Congo population from 20 to 40 million reduced to 8 million people; and finally, perhaps worst of 
1 The conservative nine million figure comes from Curtin (1969). Based on a consensus calculation of 11-12.5 million individuals transported, various demographic models concur with Curtin that for each individual transported, one individual died. However, other demographic models use multiplying factors of two to five, taking into account deaths during capture, deaths all, it resulted in the triumphant introduction of such means of pacification into ordinary, respectable foreign policies. (Arendt 1976, 185)

Attentive to this passage's evasive substitution of psychological motives for economic ones, Michael Rothberg argues “Arendt's figuration of the colonized in Africa ... provides the grounds for her path-breaking analysis of the Nazi camps, but in such a way that it confirms the racist suppositions of colonial logic" $(2009,37)$. Perhaps this conflicted analysis helps account for her conflicted analysis of Kafka's prophetic powers, which she composed at the same time she was working on The Origins of Totalitarianism. In her 1944 essay for the Paris Review, "Franz Kafka: A Revaluation (On the occasion of the twentieth anniversary of his death)," she writes: "Kafka's so-called prophecies were but a sober analysis of underlying structures which today have come into the open" $(1994,74)$. In spite of centuries of well-publicized, even celebrated depredations in Africa, somehow only the Nazis' programme of bureaucratized genocidal enslavement of the Jews emerged from "underlying structure ... into the open." While negating Kafka's prophetic mantle, Arendt nonetheless credits him with a sort of heroic x-ray vision.

What The Origins of Totalitarianism does not see, and what this essay argues Kafka did see, with perceptive if not x-ray vision, was that before the plundering and murder of the Herero and the Jews, technological and bureaucratic mediation were central to and enabled by the transatlantic slave trade and the plantation regimes of the New World, whose death toll since the Portuguese began exporting slaves from Congo in the mid-fifteenth century until Brazil abolished slavery in 1889 has been estimated at anywhere from nine to sixty million. ${ }^{1}$ Eric Williams, historian and first Prime Minister of independent Trinidad, outlines in Capitalism and Slavery the vicious feedback loop by which the slave trade - geared toward "vast sugar factories owned by a camarilla of absentee capitalist magnates and worked by a mass of alien proletarians" that anticipated European factory labour by two hundred years generated the capital plowed into innovations in chemistry, metallurgy, textiles, and mechanical engineering that yielded an Industrial Revolution whose technologies and practices were worked out in the colonies first (1944, 24). Complementing Williams' attention to technology and commodity capital, in Specters of the Atlantic Ian Baucom details how, since the eighteenth century, the slave trade formed a crucial part of the bureaucracy of finance capital, focusing in particular on the history of maritime insurance and the emergence of speculative, fictitious values by which the prospects of "human cargo" became fungible, trade-able, financial vehicles massively amplifying the credit economy that enabled Europe's domination of the world economy (Baucom 2005, 8). 
during transport to the coastal slave factories, deaths in the coastal slave factories themselves, deaths at sea, and death upon arrival in the New World due to seasoning, disease, suicide, etc.
In other words, the fashioning of Kafka as a clairvoyant who anticipated Auschwitz out of an alchemy of his personal genius and his empirical observation of an isolated Europe erases his extensive textual, photographic, and biographical encounters with the technological and bureaucratic mediations of circum-Caribbean and Black Atlantic racial capitalism, encounters that crystallize within "In the Penal Colony." With the notable exceptions of John Zilcosky and Mark Christian Thompson, who will be taken up below, it is precisely the question of Blackness that has been scrubbed out of view in this story even by postcolonial critics who, as Lemon bemoans, "subsume the text under the general rubric of colonialism" $(2007,281)$. The point, of course, is not to insist that "In the Penal Colony" is really about Black prisoners in Caribbean colonies (though it could be), but to ask what happens when we open up the interpretive field not only to the abstract mapping of power relations (Rutherford 2001; Cumberland 2013), or histories of the Austro-Hungarian Empire (Streit 2014), for example, but also to the colonial political economies and techno-juridical regimes producing Blackness that we know Kafka was not oblivious to, was in fact interested in.

Numerous traces of this interest appear and resonate in the text. First, "In the Penal Colony" taps an extensive island-oriented colonial discourse in German culture, in which the Caribbean played a major role. Imperial Germany constantly angled to establish itself in the region, attempting to claim Martinique as war-booty after the 1870 Franco-Prussian War and participating in the international debt-reclamation naval intervention against Venezuela in 1905 (Mitchell 1997, 37, 53, 64-107). Prior to the Wilhelmine period, the Caribbean, both as scene of slave uprisings and as the setting of Robinson Crusoe, whose eponymous protagonist ends up stranded on a deserted Caribbean island in the aftermath of a slaving venture between West Africa and Brazil, was foundational for the German colonial imagination. Susanne Zantop, the late pioneer of postcolonial German cultural studies, comments:

To German (and probably not just German) readers, "islands” had been synonymous with "colony" ever since Defoe's Robinson Crusoe had initiated an avalanche of Robinsonades, among them Schnabel's influential Die Insel Felsenburg (1731-1743), in which German colonists establish a model colony on a fictitious island. (Zantop 1997, 37-38)

Such Robinsonades were massively popular in German even into the twentieth century, and we find Kafka writing about his perennially beloved Robinson Crusoe in a letter to Max Brod as late as 1922 (Kafka 1958, Br. 392). Whether geared toward children or adults, or religious or secular audiences, Robinsonades shared with Defoe's text an impulse to imagine in the tropical 
islands "a model colony," an impulse whose political unconscious "In the Penal Colony" exposes through its juridical dystopia. German Romanticism would also inflect the island discourse. Against the backdrop of the revolutions in America and Haiti and Napoleon's conquest of German-speaking Europe, as Johann Reusch argues, Caspar David Friedrich's seminal painting "Monk by the Sea," inspired by "cultural and intellectual maverick, the poet and pastor Ludwig Kosegarten ... the 'Nordic bard'," maps onto the once Slavic Rügen Island in the North Sea the "pre-Roman," heroic German impulse to freedom $(2003,349)$.

Precisely the erasure of the Caribbean from this conceptual constellation of island, colony, slavery, and freedom - a constellation plainly at work in "In the Penal Colony" - preoccupies the work of Pierre-Franklin Tavarès and Susan Buck-Morss. Building off the former's largely ignored Hegel research (Tavarès 1992), the latter asks: “'Where did Hegel's idea of the relation between lordship and bondage originate?' ask the Hegel experts, repeatedly. Where indeed?" (Buck-Morss 2000, 842). As his letters and journals attest, Hegel closely followed the events of the Haitian Revolution in the preeminent European political journal of the day, Minerva, which covered the events in Saint-Domingue in depth. "We are left with only two alternatives," BuckMorss concludes:

Either Hegel was the blindest of all the blind philosophers of freedom in Enlightenment Europe, surpassing Locke and Rousseau by far in his ability to block out reality right in front of his nose (the print right in front of his nose at the breakfast table); or Hegel knew - knew about real slaves revolting successfully against real masters, and he elaborated his dialectic of lordship and bondage deliberately within this contemporary context. (Buck-Morss 2000, 844)

Are we here dealing with a similar erasure of an author's "deliberate" elaboration of a text in relation to a Caribbean context? I'm less interested in Kafka's intent than in the relative absence of the Caribbean and New World slavery from the intertextual field scholars draw upon in their discussions of "In the Penal Colony." Ignoring the Caribbean echoes of "In the Penal Colony" not only reflects a Eurocentric failure to apprehend the racialized imaginaries and colonial discourses shaping German-language art and letters, but also misses the opportunity to globalize Kafka in new ways, to recognize in Kafka's story a "mirror of tomorrow" that perhaps saw in Caribbean history reflections of the horizon of world history.

The characterizations of "In the Penal Colony" also suggest an intimate engagement with German colonial discourse on the islands of the New World. The Traveler closely aligns with a specifically German relationship to the European colonial project, one that emerged in the eighteenth 
century as the German states and principalities found themselves excluded from the possession of overseas colonies. Zantop writes:

There was indeed a special role, function, or interest for Germans, which derived from their position as outsider looking in. Precisely because they were not involved in current colonizing activity and had no apparent interest at stake, German readers were freer to assume the distanced, "disinterested" voice of the critic who discusses issues "systematically" and "in principle." Hence they compiled, edited, evaluated, and processed any information available on colonial activities. They examined the authenticity of reports and questioned their veracity. They went back to the sources and compared them with newer documents. A critical awareness of the tendency to fictionalize and an endeavor to separate myth from fact characterized most of their comments. (Zantop 1997, 39)

In keeping with this portrait of the "disinterested" German role in the production of colonial knowledge, encompassing texts such as Alexander von Humboldt's 1826 Essai politique sur l'isle de Cuba, the narrator of "In the Penal Colony" testifies: "No one could assume that the Traveler was acting out of any sense of his own self-interest" (9). As the Traveler attempts to evaluate the judicial processes of the penal colony, the story closely mimics the debates between colonial elites and metropolitan commentators tracked in such monumental histories as Robin Blackburn's The Overthrow of Colonial Slavery, 1776-1848 (Blackburn 1988 [2011], 131-212) and David Brion Davis's The Problem of Slavery in the Age of Revolution, 1770-1823 (39-83). The Traveler thinks to himself: "The injustice of the process and the inhumanity of the execution were beyond doubt" (9). Perceiving the Traveler's sentiments, and echoing the pro-slavery Antillean hardliner's response to the anti-slavery proclamations emanating out of Revolutionary Paris, abolitionist London, or Humboldt's Aufklärung, the Officer superciliously informs the Traveler: "You are now in your second day on the island... You are trapped in a European way of seeing things" (11). The Officer asserts the superiority of local knowledge over the "disinterested," "abstract," and "idealistic" discourse of the metropole.

The Officer comes to define the penal colony as a "state of exception," in Giorgio Agamben's phrase, an Arendtian "emergency" that disqualifies standards of metropolitan jurisprudence. The irremediable criminality of the accused in the colony - "Guilt is always beyond a doubt" - underwrites this state of exception. In this, the juridical logic of Kafka's fictional universe overlaps considerably with the narratives of New World slavery and racialized capitalist exploitation he consumed. Along with Defoe, probably the most important author in this respect for Kafka was Oskar Weber. Kafka owned three books by Weber: Der Zuckerbaron: Schicksale eines ehemaligen deutschen offiziers in Südamerika (The Sugar Baron: Adventures of a Former 
German Officer in South America); Briefe eines Kaffee-Pflanzers. Zwei Jahrzehnte deutscher Arbeit in Zentral-Amerika (Letters of a Coffee Planter: Two Decades of Work in Central America); Der Bananenkönig. Was der Nachkomme eines Verkauften Hessen in Amerika schuf (The Banana King: What the Descendant of an Indentured Hessian Created). Kafka's archive does not allow us to downplay the importance of Weber. In a letter to on-again, off-again fiancée Felice Bauer, Kafka wrote: "One book that is as close to me as if it dealt with my own life, or as though it were a formula [Vorschrift] for my life, which I just manage to elude ... is The Sugar Baron" (cited in Neumeyer 1971, 6).

The Sugar Baron narrates the memoirs of a military land-surveyor (Vermesser) who establishes a sugar-cane plantation in Central America. Peter Neumeyer, the first Kafka scholar to explore Kafka's relationship to this book, and Schaffstein Verlag's Grüne Bändchen (Little Green Books) series it was part of more generally, argues for an extensive sympathy between Kafka and Weber, and suggests the Sugar Baron himself offered a "formula" for Kafka's life "which [he] just managed to elude," devoting himself to literature rather than following Uncle Josef to Panama or the Congo. One of the main planks of this argument lies in both authors' fondness for technical descriptions of machines and apparatuses. Two mechanisms central to The Sugar Baron's technical style converge in "In the Penal Colony:" the sugar-cane press and the stocks. While Neumeyer perceives the mechanical similarities between "the sugar press and the Penal Colony machine" (Neumeyer 1971, 10), Kafka's text inscribes deeper, politically charged similarities between the economic and the disciplinary apparatuses. John Zilcosky's pioneering postcolonial study Kafka's Travels notes these similarities through a discussion of the recurrent appearance of the verb auspressen (to press out, to crush) $(2003,114)$. For Weber and Neumeyer, the stocks simply represent a "police technology ... in which the drunk or murderous miscreant may be pacified" (Neumeyer 1971, 10). Yet the stocks function in The Sugar Baron as one of many disciplinary instruments by which Weber establishes joint legal and economic dominion over his plantation workers, pressing out their labour and crushing their miscreance. So perhaps this plantation world where chattel-like subalterns "think no more than the mule" generated something other than sympathy for Weber in Kafka (Weber 1971, 17), who in the immediate aftermath of reading The Sugar Baron in 1914 lampooned the presumed bestiality of enslaved Africans in "A Report to an Academy" (Kafka [1914] 1971, 281-290). Perhaps Kafka, who devoted his professional career to worker injuries in the factories of Bohemia, perceived something other than technical coincidence between instruments of economic exploitation and those of corporal punishment.

In other words, the New World sugar plantation compellingly models the "state of exception" that defines the juridical world of Kafka's fictions. 
Kafka articulates the penal colony with plantation colonies in multiple ways. The Officer's control of the judicial process intensifies the conflation of "criminal and colonial" that Richard Price $(1998,88)$ observes in French Guiana, Antillean site of Dreyfus's imprisonment on Devil's Island, about which Kafka was well-read:

Here in the penal colony I have been appointed judge. In spite of my youth. For I stood at the side of our Old Commandant in all matters of punishment, and I also know the most about the apparatus. The basic principle I use for my decisions is this: Guilt is always beyond a doubt. Other courts could not follow this principle, for they are made up of many heads and, in addition, have even higher courts above them. (5)

With this reiterated staging of the "superiority" of local jurisprudence over and against metropolitan interference, Kafka's penal colony comes more and more to resemble a plantation-based settler colony, such as Guadeloupe under Victor Hugues rejecting Revolutionary France's abolition of slavery. The characterization of the island's residents intensifies this resemblance. While the Officer speaks French, "clearly neither the Soldier nor the Condemned Man understood the language" (2). On this diglossic island, the crowds of well-dressed French-speaking women who attend the spectacles of punishment furthermore suggest not a mere prison island, but a functioning colony. As for the condemned themselves, the story figures them as inescapably guilty ("Guilt is always beyond a doubt") and always already in pain: "for the first six hours [of punishment] the condemned man goes on living almost as before. He suffers nothing but pain" (8, my italics). Inescapably guilty, always already in pain: such is the juridical construction of the slave. Saidiya Hartman points out in Scenes of Subjection that "criminality is the only form of slave agency recognized by law" (1997, 41). Slaves otherwise register in legal discourse only as "pained bodies" (51), injured chattel-property whose masters can sue for indemnification, or bodies on the verge of corporal punishment, "subject," Elsa Goveia notes, "to public repression and private tyranny" (1960, 103).

The plantation regime, then, like Kafka's fictional universe, fashioned a juridical "state of exception" where subjects register as always already guilty, always already in pain, always already on the verge of spectacular punishment. The stocks, the apparatus, the whip, the noose: we should not be surprised to learn, at this point, that Kafka kept close at hand a picturepostcard of an Oklahoma lynching, "a photograph labeled 'Idyll in Oklahoma'," of smiling white faces gathered around a suspended Black corpse (Hofmann 2002, xi). This postcard partly inspired "the Nature Theater of Oklahama" section of Kafka's fragmentary novel Der Verschollene (The Man Who Disappeared), also known as Amerika, in which the European 
immigrant Karl Rossman officially registers his name as "Negro." Yet whereas Der Verschollene, according to Goebel, insists on "the stereotypical affiliation of minority status with menial labor," "In the Penal Colony" "far surpasses Karl's unsuccessful mediation between his European consciousness and American society" symbolized by his self-inscription as Black (Goebel 2002, 197). Hewing ever more closely to the postcard, "In the Penal Colony" draws our attention to the tortured body of the Condemned Man, apprehending the Law not through a visual scanning of its tomes, nor at a hearing before its judge, but on the pained body itself. We here witness what Mark Christian Thompson in Kafka's Blues - evoking Frantz Fanon's ontology of Blackness as alienable, fungible signifier, "Les nègres sont la comparaison" $(1952,197)$ - argues is central to the experience of law and power in Kafka: the passing through "a contextual and corporeal state of being 'Negro'," the harrow, like the whip and the noose, lacerating the "essential script" (Thompson 2016, 3).

Attuning an interpretation of "In the Penal Colony" to Kafka's Black Atlantic intertextualities brings into view the consonance of the story with circum-Caribbean legal codes and penal processes, as well as the dynamic of their observation by metropolitan travellers. Once again, the point here is not to impose an exclusive, one-to-one correspondence between New World plantation society and "In the Penal Colony," but to point out the marks, signs, structures, and scars of a slavery that constitutes one of the myriad codes constituting Kafka's discourse. Precisely the pertinence of New World slavery to the story's mise en scène, its irresistible racialized resonance both through the visual inscription of domination on the body of the condemned, as well as through the discursive construction of the condemned in terms identical to slave jurisprudence, register a historiographical intervention that "forsees" what Samolsky calls the text's "future to come" (1999, 192). Just as the story itself turns on a reversal, with the Officer seeking for himself the machine-mediated punishment he so relished inflicting on others, swapping sadism for masochism (Zilcosky 2003, 103) with a spectacular and suicidal devotion to the symbols of his endangered supremacy, so too does the story's assertion of a Black subtext reverse and reorient the proleptic flow of Kafka's Prague-to-Auschwitz vision toward a retrospective gaze from twentieth-century Europe to the epoch of transatlantic slavery.

For planters like Bryan Edwards of Jamaica, slave jurisprudence, and its attendant reign of "public repression and private tyranny," was a matter of necessity, "that absolute coercive necessity which, leaving no choice of action, supercedes all questions of right" (cited in Goveia 1960, 107). As noted above, this supercession of "all questions of right" aligns with the suspension of rights Agamben discusses under the rubric of the state of exception. For Agamben, famously, and despite Nazi jurists' deferential regard for the legislative transition from slavery to Jim Crow that earned the United 
States their dubious distinction of being the "innovative world leader in the creation of racist law" and therefore "Hitler's American model" (Whitman 2017, 2), Nazi Germany offers the exemplary model of the state of exception:

The entire Third Reich can be considered a state of exception that lasted twelve years. In this sense, modern totalitarianism can be defined as the establishment, by means of the state of exception, of a legal civil war that allows for the physical elimination not only of political adversaries but of entire categories of citizens who for some reason cannot be integrated into the political system. (Agamben 2005, 2)

As we saw above, before the National Socialists sought to exclude, concentrate, and eliminate Jews (and others) from the German political system, their predecessors in the German General Staff implemented similar policies against the Herero. As a self-proclaimed matter of "emergency" and "absolute coercive necessity," European governments had been following this playbook during centuries of settler colonialism, with thousands of Oskar Webers establishing coffee, cotton, banana, and sugar plantations that subjected millions of Blacks and Amerindians, "drunks and murderous miscreants," to exorbitant regimes of disenfranchisement, corporal punishment, and fatally exhaustive labour. As Frank B. Wilderson III comments: “Agamben is not wrong so much as he is late. Auschwitz is not 'so unprecedented' to one whose frame of reference is the Middle Passage, followed by Native

2 "Jews went into Auschwitz and came out as Jews. Africans went into the ships and came out as Blacks. The former is a Human holocaust; the latter is a Human and a metaphysical holocaust. That is why it makes little sense to attempt analogy: the Jews have the Dead (the Muselmann) among them; the Dead have the Blacks among them. This violence which turns a body into flesh, ripped apart literally and imaginatively, destroys the possibility of ontology because it
American genocide." 2 These anterior "scenes of subjection" could offer up case studies of "a legal civil war that allows for the physical elimination not only of political adversaries but of entire categories of citizens." Yet in the embrace of Agamben, as for Kafka's interpreters, Auschwitz crowds centre stage.

According to Naomi Mandel, "For Lyotard, Agamben, Blanchot, and Derrida the Holocaust... is a catalyst that activates a sense of moral urgency and heightens the discussion's implicit stakes" (2006, 32-33). The looming presence of Auschwitz at the centre of Kafka's prophetic prestige, like its role Mandel identifies in continental philosophy as a "catalyst" for moral urgency, begs an important question. The genocidal depredations of Black Atlantic and circum-Caribbean history offered Kafka nightmarish juridical worlds of masters and slaves, officers and convicts, judges and plaintiffs, planters and peons. Somehow, though, for large numbers of Kafka's interpreters, even in spite of Arendt's insistence on the genealogical significance of imperialism in Africa, these erased precedents have not been enough to inspire "multidirectional memory" that Rothberg calls "productive rather than privative" $(2009,3)$ : Auschwitz above all fuels the incandescence of Kafka's prophecy. 
positions the Black in an infinite and indeterminately horrifying and open vulnerability, an object made available (which is to say fungible) for any subject" (Wilderson 2010, 36, 38).
3 In the contemporary European context, for example, Speccher (2013, 191), expounds upon "the dead Jew as the Other that is desired."
Similarly, forming part of an emergent Caribbeanist critique of the embrace of Agamben's work, Jamaican theorist David Scott interrogates a "particular politics of making some histories relevant, and others not:"

But why should we be obliged to submit to the semiotic inflation that makes the Holocaust the primal scene of the original crime, and the extermination camp the fundamental paradigm, of modern Western power? What Western anxiety - what desire - drives this philosophico-political exorbitance? ... And since our immediate concern is with the figure of the slave, let's think of the Zong, that "exemplary" eighteenth century slave ship traversing the Middle Passage with its liminal "cargo" of living dead, each but an ink-mark in an accounting ledger...

What more poignant image of sovereign power and bare life? How, I wonder, would Agamben consider this instance? What political philosophy might it animate as the generative metaphor for the state of exception that defines our collective present? (Scott 2007, ix)

Scott's critique does not seek to adjudicate scales of atrocity, but instead to query the "desires" driving intellectual labour. Beyond the uneven desires for one exemplary victim over another, ${ }^{3}$ both Kafka and Agamben, in their ways, are figures of desire: Kafka, tragic prophet from a disappeared world, long ago became an inspiration and an industry; Agamben's "celebrity" far outstrips what political theorists can hope to expect, and his terminology resonates across the worlds of art, activism, and academia. This resonance owes an explicit debt to Kafka; as monographs by Matthew Calarco (2007, 192193) and Anke Snoek (2012) document, Agamben's philosophy repeatedly turns to Kafka in order to animate what Caribbeanist scholar Sibylle Fischer argues "is the most urgent issue in contemporary political theory: the dehumanization entailed by the exclusionary transformation of citizens and political subjects into subjects of management and control" (2007, 8). Like Scott, Fischer bemoans the absence of slavery and colonialism from Agamben's “argument that moves from the Greek polis to Hobbes, the French Revolution, to Auschwitz;" however, this absence helps explain Agamben's appeal:

the abstract graphicness of the concept of 'bare life' and the lack of contextual detail in the theory that produces it, make it available for a highly ambiguous fantasy investment. We do not need to get entangled in complexities of historical roots and causes. (8)

Abstract graphicness and the lack of contextual detail: these are the hallmarks of Kafka's "hermetic spirit" that have enabled his "disjunctive signs" to emerge as prophetic of the Holocaust, and have also propelled their recursive "reterritorialization" (Deleuze and Guattari 1986, 16-19) in literary 
traditions as diverse as Argentina under military dictatorship (Ricardo Piglia's Artificial Respiration), authoritarian Egypt (Sonallah Ibrahim's The Committee), occupied Palestine (Emile Habiby's The Secret Life of Saeed: The Pessoptomist), communist Yugoslavia (Danilo Kiš, A Tomb for Boris Davidovic), and post-9/11 US empire (Kate Scott, Kafka in Cuba: The Afghan Experience in Guantánamo). These works, and countless others, join a chorus from George Steiner to J. Hillis Miller that proclaim Kafka's prescience, his prophecy of a coming world of murderous techno-bureaucratic dehumanization. Yet Kafka's archive, exceeding what Wilderson calls "the circulation of Blackness as metaphor and image... inessential to and parasitic on the Black" $(2010,22)$, lays bare precisely what was not abstract and lacking in contextual detail: juridically sanctioned, bureaucratically mediated processes of enslavement, deportation, industrialized labour, and corporal punishment within Africa and across the Middle Passage into the New World. Perhaps not Kafka, then, but the colonial political economies of the Black Atlantic and circum-Caribbean he took so much interest in, had been predicting our future all along, "as though it were a formula which [he, unlike his sisters, who died at Auschwitz] just manage[d] to elude." Perhaps we can read another "preparatory anxiety" inscribed in Kafka's text, one that predicted how future readers would be, like his Traveler, "trapped in a European way of seeing things," and that among the many reversals of this story, was a way out.

\section{References}

Adorno, Theodor W. 1981. "Notes on Kafka." In Prisms. Translated by Samuel Weber and Shierry Weber, 243-270. Cambridge, MA: MIT Press.

Agamben, Giorgio. 2005. State of Exception. Translated by Kevin Attell. Chicago: University of Chicago Press.

Anders, Günther. 1960. Franz Kafka. Translated by A. Steer and A. K. Thorlby. London: Bowes \& Bowes.

Arendt, Hannah. 1976. The Origins of Totalitarianism. New York: Harcourt.

Arendt, Hannah. 1994. "Franz Kafka: A Revaluation (On the Occasion of the Twentieth Anniversary of His Death)." In Essays in Understanding, 19301954: Formation, Exile, Totalitarianism, edited by Jerome Kohn, 69-80. New York: Schocken.

Baranowski, Shelley. 2011. "Against 'Human Diversity as Such': Lebensraum and Genocide in the Third Reich." In German Colonialism: Race, the Holocaust, and Postwar Germany, edited by Volker Langbehn, and Mohammad Salama, 51-71. New York: Columbia University Press.
Baucom, Ian. 2005. Specters of the Atlantic: Finance Capital, Slavery, and the Philosophy of History. Durham, NC: Duke University Press.

Benjamin, Walter. 1969. "Some Reflections on Kafka." In Illuminations: Essays and Reflections, edited by Hannah Arendt, 141-145. Translated by Harry Zohn. New York: Schocken.

Blackburn, Robin. 1988 [2011]. The Overthrow of Colonial Slavery, 1776-1848. London: Verso.

Bley, Helmut. 1971. South-West Africa under German Rule, 1894-1914. Evanston: Northwestern University Press.

Boa, Elizabeth. 1996. Kafka: Gender, Class and Race in the Letters and the Fictions. Oxford: Clarendon Press.

Born, Jürgen. 1990. Kafkas Bibliothek. Ein beschreibendes Verzeichnis. Mit einem Index aller in Kafkas Schriften erwähnten Bücher, Zeitschriften und Zeitschriftenbeiträge. Zusammengestellt unter Mitarbeit von Michael Antreter, Waltraud John und Jon Shepherd. Frankfurt am Main: S. Fischer. 
Buck-Morss, Susan. 2000. "Hegel and Haiti.” Critical Inquiry 26 (4): 821-865.

Calarco, Matthew. 2007. Giorgio Agamben: Sovereignty and Life. Palo Alto: Stanford University Press.

Césaire, Aimé. 1955. Discours sur le colonialism. Paris: Présence Africaine.

Cumberland, Ruth. 2013. "Inscribed Bodies: The Cruel Mirage of Imperialistic Idealism in Kafka's Penal Colony." Papers On Language \& Literature 49 (2): 203-222.

Curtin, Philip D. 1969. The Atlantic Slave Trade: A Census. Madison: University of Wisconsin Press.

Deleuze, Gilles, and Felix Guattari. 1986. Kafka: Toward a Minor Literature. Translated by Dana Polan. Minneapolis: University of Minnesota Press.

Fanon, Frantz. 1952. Peau noire, masques blancs. Paris: Seuil.

Fischer, Sibylle. 2007. "Haiti: Fantasies of Bare Life." Small Axe: A Caribbean Journal of Criticism 23 (2): 1-15.

Gilman, Sander L. 1995. Franz Kafka: The Jewish Patient. New York: Routledge.

Goebel, Rolf. 1997. Constructing China: Kafka's Orientalist Discourse. Rochester: Camden House.

Goebel, Rolf. 2002. "Kafka and Postcolonial Critique: Der Verschollene, 'In der Strafkolonie,' and 'Beim Bau der chinesischen Mauer'.” In A Companion to the Works of Franz Kafka, edited by James Rolleston, 187-212. Rochester: Camden House.

Goveia, Elsa V. 1960. "The West Indian Slave Laws of the Eighteenth Century." Revista de Ciencias Sociales 4 (Marzo): 75-105.

Gray, Richard. 2002. "Disjunctive Signs: Semiotics, Aesthetics, and Failed Mediation in 'In der Strafkolonie'." In A Companion to the Works of Franz Kafka, edited by James Rolleston, 213-245. Rochester: Camden House.

Hartman, Saidiya. 1997. Scenes of Subjection: Terror, Slavery, and Self-making in Nineteenth-Century America. New York: Oxford University Press.

Hartmann, Wolfram, Jeremy Silvester, and Patricia Hayes, eds. 1999. The Colonising Camera: Photographs in the Making of Namibian History. Athens: Ohio University Press.

Hecker, Axel. 1998. "Die Dekonstruktionsmaschine 'In der Strafkolonie'.” In An den Rändern des Lesbaren: Dekonstruktive Lektüren zu Franz Kafka, 79119. Vienna: Passagen.

Heydrich, Robert. 2016. "Protocol of the Proceedings of the Wannsee Conference." January 1942. Facsimile Reproduction of Original Memo on Display at the Haus der Wannsee-Konferenz, Wannsee, Germany.
Hofmann, Michael. 2002. Introduction to Amerika (The Man Who Disappeared). Translated by Michael Hofmann. New York: New Directions.

Janouch, Gustav. 1971. Conversations with Kafka. Translated by Goronwy Rees. New York: New Directions.

Kafka, Franz. 1958. Briefe 1902-1924. Edited by Max Brod. Frankfurt am Main: S. Fischer.

Kafka, Franz. [1914] 1971. “A Report to an Academy.” In The Complete Stories of Franz Kafka, edited by Nahum Glazer, 281-290. Translated by Willa and Edna Muir, Tania and James Stern. New York: Schocken.

Kafka, Franz. 1975. In der Strafkolonie. Eine Geschischte aus dem Jahre 1914, mit Quellen, Abbildungen, Materialen aus der Arbeiter-Unfall-Versicherungs-Anstalt, Chronik und Anmerkungen von Klaus Wagenbach. Berlin: Wagenbach.

Kafka, Franz. n.d. "In the Penal Colony." Translated by Ian Johnston. Nanaimo: Vancouver Island University.

Langbehn, Volker, and Mohammad Salama, eds. 2011. German Colonialism: Race, the Holocaust, and Postwar Germany. New York: Columbia University Press.

Langer, Lawrence L. 1995. "Kafka as Holocaust Prophet - A Dissenting View." In Admitting the Holocaust: Collected Essays, 109-124. New York: Oxford University Press.

Lemon, Robert. 2007. "Cargo Colonies and Penal Cults: Ethnology and Ethnocentrism in Kafka's 'In der Strafkolonie'." Colloquia Germanica 40 (3/4): 279-295.

Mamdani, Mahmood. 2001. When Victims Become Killers: Colonialism, Nativism, and the Genocide in Rwanda. Princeton: Princeton University Press.

Mandel, Naomi. 2006. Against the Unspeakable: Complicity, the Holocaust, and Slavery in America. Charlottesville: University of Virginia Press.

Megargee, Geoffrey P., ed. 2009-present. Encyclopedia of Camps and Ghettos, 1933-1945. Washington, DC: United States Holocaust Memorial Museum. https://www.ushmm.org/research/publications/ encyclopedia-camps-ghettos.

Miller, J. Hillis. 2011. Conflagrations of Community: Literature Before and After Auschwitz. Chicago: University of Chicago Press.

Mitchell, Nancy. 1997. The Danger of Dreams: German and American Imperialism in Latin America, 1895-1914. Chapel Hill: University of North Carolina Press.

Müller-Seidel, Walter. 1986. Die Deportation des Menschen: Kafkas Erzählung «In der Strafkolonie» im europäischen Kontext. Stuttgart: Metzler.

Neumeyer, Peter F. 1971. "Franz Kafka, Sugar Baron." Modern Fiction Studies 17 (1): 5-16. 
Northey, Anthony. 1991. Kafka's Relatives: Their Lives and His Writing. New Haven: Yale University Press.

Price, Richard. 1998. The Convict and the Colonel. Boston: Beacon Press.

Reusch, Johann J. K. 2003. "Exotic Islands and the Stranded Traveler in the Works of Caspar David Friedrich." Studies in Eighteenth Century Culture 32: 347-369.

Rothberg, Michael. 2009. Multidirectional Memory: Remembering the Holocaust in the Age of Decolonization. Stanford: Stanford University Press.

Rutherford, Danilyn. 2001. "The Foreignness of Power: Alterity and Subversion in Kafka's "In the Penal Colony" and Beyond." Modernism/Modernity 8 (2): 303-313.

Said, Edward. 1993. Culture and Imperialism. New York: Knopf.

Samolsky, Russell. 1999. "Metaleptic Machines: Kafka, Kabbalah, Shoah.” Modern Judaism 19 (2): 172-192.

Scott, David. 2007. "Preface: Soul Captives are Free." Small Axe 11 (2): v-x.

Sharpe, Christina. 2016. In the Wake: On Blackness and Being. Durham, NC: Duke University Press.

Snoek, Anke. 2012. Agamben's Joyful Kafka: Finding Freedom Beyond Subordination. New York: Bloomsbury Academic.

Speccher, Tommaso. 2013. "The Dead Jew as Eternal Other." In Contemporary Jewish Reality in Germany and Its Reflection in Film, edited by Claudia Simone Dorchain, and Felice Naomi Wonnenberg, 189-204. Berlin: Walter de Gruyter.
Steiner, George. 1970. “K.” In Language and Silence: Essays on Language, Literature, and the Inhuman, 118-126. New York: Atheneum.

Streit, Wolfgang. 2014. Die Transparenz der Folter: Franz Kafkas "In der Strafkolonie" aus Sicht der Postkolonialismus-Forschung. Noderstedt: Books on Demand Verlag.

Tavarès, Pierre-Franklin. 1992. "Hegel et Haiti ou le silence de Hegel sur Saint Domingue." Chemins Critiques, Revue Haïtiano-Caraíbéenne 2 (3): 113-131.

Thompson, Mark Christian. 2016. Kafka's Blues: Figurations of Racial Blackness in the Construction of an Aesthetic. Evanston, IL: Northwestern University Press.

Weber, Oskar. 1971. "Chapter Fourteen, 'The Second Home,' from The Sugar Baron: South American Adventures of a Former German Officer." Translated by Peter F. Neumeyer. Modern Fiction Studies 17 (1): 17-25.

Whitman, James Q. 2017. Hitler's American Model: The United States and the Making of Nazi Race Law. Princeton: Princeton University Press.

Wilderson III, Frank B. 2010. Red, White and Black: Cinema and the Structure of US Antagonisms. Durham, NC: Duke University Press.

Williams, Eric. 1944. Capitalism and Slavery. Chapel Hill: University of North Carolina Press.

Zantop, Susanne. 1997. Colonial Fantasies: Conquest, Family, and Nation in Precolonial Germany, 17701870. Durham, NC: Duke University Press.

Zilcosky, John. 2003. Kafka's Travels: Exoticism, Colonialism, and Traffic of Writing. New York: Palgrave. 